\title{
The Genesis of Corruption - the Dominant Features of Contemporary Societies of the Colonial Past Inheritance
}

\author{
Miroslav Kuka, $\mathrm{PhD}^{1,2}$ \\ ${ }^{1}$ Faculty of Education, University "St. Kliment Ohridski”, Bitola, North Macedonia \\ ${ }^{2}$ Academy for Educational and Medical Studies in Krusevac, Republic of Serbia \\ E-mail: miroslav.kuka@kuka-grosmeister.com
}

Received: July 5, 2021 Accepted: August 10, $2021 \quad$ Published: August 11, 2021

doi:10.5296/ijssr.v9i2.18931ＵRL: https://doi.org/10.5296/ijssr.v9i2.18931

\begin{abstract}
One of the most significant characteristics of the contemporary society is the continuous and an intense social change. This continuous social change initiates a special subject of research into social practice, which envisages in social innovations, influencing to change the life style of citizens of a society. Social innovations are encouraged through the interaction of the institutional networks and individuals and changes can be visible in practice, processes, business models, and organizational forms, all in order to respond to a social problem. In addition to historical and political conditions, social innovations are also determined through cultural patterns, in a manner that not every social innovation will aim to develop potential and seek to answers to social problems. In contemporary societies of the 21 st century with a colonial past (inheritance), the inherited cultural and historical patterns are just the crucial components which creating social problems, by developing organizational models of corruption, as a parallel form of functioning of the rule of law. The institutional practice within the Serbian institutions through a direct research in the form of this paper, considering period from 2009 to 2021, serves to analyze the genesis of the emergence and development of corruption, i.e., an illegal use of the system of positions (status) for the purpose of gaining one's own benefit and collapsing the rule of law. Simultaneously, the paper provides with a hypothetical answer to explain how corruption, as the primary form of a social innovation in the countries of "colonial democracy inheritance", can potentially suppress.
\end{abstract}

Keywords: social structure, psychology of personality, contemporary society, archetype of cultural heritage, corruption, fight against corruption 


\section{Introduction}

The term "society" determines a group of people who establish a social system within their mutual interaction takes place. Each society has its own structure, and the basic elements of the structure, through which a society is institutionalized as follows: 1) The system of roles, i.e., a horizontal organization of a society, 2) The system of positions (status), i.e., vertical organization of a society and 3) The system of values i.e., normative system, which represents the cornerstone to establish vertical and horizontal organization. Although the roles are closely related to the position (status), there is still a difference. Status is a set of rights (entitlements) and duties (liabilities), deriving from the position of an individual in a society, and the role determing a dynamic aspect of status, i.e., turning those rights (entitlements) and duties (liabilities) into action. Status acquires the significance of a position (status), in relation to the distribution of reputation, power and prestige, within a social system.

The "rule of law" takes over a monopoly of power in a certain social community, representing a concept in which the action of a state power is based on laws and constitution. The basic principle of the "rule of law" integrates all legal rules that entered into force, in order to provide an equal effect on all citizens in order to protect them against the potential abuses. Citizens in the "rule of law" are the consumers of the civil rights that can be protected and exercised through the courts of law. However, as soon as citizens begin to feel that their civil rights are threatened, the suspicion that the legal rules in force do not have an equal effect on all citizens, and if that civic feeling is maintained continuously without a change, a social environment called anarchy (powerlessness) emerges on scene. The social environment represents a cultural context in which an individual lives in an interaction with the other people and the social structures, while the corruption, a form of an organization of the social environment in which the authority of the rule of law is annulled and the new "corrupt rules" are imposed. The goal of the newly introduced "corrupt rules" is to infiltrate into the social environment, in the form of a newly established, dominant patterns of interaction between people and social structures. Comprehend in a methodological and strategic manner, corruption annuls all forms of imposed authority of the "rule of law", but still does not aim to destroy its legal rules. The most common manifestation of corruption in a contemporary society is the construction and functioning of a parallel system of corruption in the system of "legal rules", but in a manner of an independent and dominant system, within which structure a limited number of corrupt individuals are in function.

Therefore, the collapsed concept of the "rule of law" is the most frequently manifested through an institutional corruption, i.e., inter-connections (inter-personal, party or interest based) of one group of corrupted individuals, who commit corrupt acts, with another group of corrupted individuals, who cover up the committed corruption institutionally (police or judiciary system). Corrupted individuals appear in a social environment as a consequence of the non-existence of the "rule of law", while considering the psychological aspect, they have a characteristic predisposition to socially function in contradiction and inconsistence with the law and the constitution, i.e., imposed legal rules. The aforementioned is explained by the fact that each individual has his own way of perceiving and acting in a certain situation, and the one's temperament is responsible for that, i.e., an external relationship toward the external world and the character. In the context of our analysis, the crucial determination is the 
character of an individual, which implies to his inner, i.e., mental, motivational-emotional, social, cognitive characteristics, which determine reactions to certain events or situations. This is the matter of patterns of behavior, manner of thinking, self-control, etc. Specifically considered, the character of an individual, but simultaneously because of the environment in which the one is situated in, an individual determines the principles and rules of life which the one adheres to in interaction with the other people. Character is not an easy component to assess, because its peculiarities are most often revealed in specific circumstances.

If the conditions are created for the "rule of law" through its system of institutional selections, to instill corrupt individuals on position (status), then the social structure begins to be created according to the character model of these corrupt individuals. The mentioned model was described by the French King Louis's XIV - the Sun King, statement: 'L'etat, c'est moi (in original in French) "I am the state".

However, the described correlation of the formed social structures and psychology of personality is not a sufficient cause for the creation of a social environment that results in corruption as a dominant feature of the rule of law. The given example describes a possible case, which indicates the nature of human differences manifested within one social group, which still does not create a critical mass of related behavior, which would shape the social environment according to the dominant model.

\section{Contemporary Society and the Archetype of Cultural Heritage}

The division of history into periods gives a man the possibility of a critical review to his creative work. By taking a stand on past events, a man creates the present and influences the shaping (modeling, designing) of the future. In that sense, the achievements of a modern society that developed from the 16th to the 19th century shaped the concept of a contemporary society that emerged at the beginning of the 20th century. The development of a science and a technology, the ideology of "profit orientation" spreads and unifies the lifestyle, according to the model of a passive, consumer-oriented individual. The educational system develops egoism, without a compassion and empathy, while an entertainment, violence and crime are on the rise. The intense changes to which contemporary societies are exposed, do not necessarily offer solutions to the problems we face. These features of contemporary society, created from a technological progress, largely initiate the regression process of an institutional corruption, which undermines the authority of the "rule of law". In the processes of an institutional corruption, which destructively change the social structure, there are various adaptations of people occurred, in regard to legal and organizational forms of corruption.

The social structure with the dominance of institutional corruption finds its genesis in the archetype, i.e., a hypothetical construct that represents the inherited framework of the entire experience. That entire experience consists of innate patterns of thinking, feeling and acting, occurred as a result of centuries of experience of generations of ancestors. The Serbian scientist Jovan Cvijic (1865-1927), in his book "Psychic Characteristics of the Southern Slavs and Ethno psychology in Serbia", states that under the specific historical and cultural conditions, a special ethno psychic type was formed, and that is the central type, which characterized by "the Rhine mentality". This type originated from the central part of the 
Balkan Peninsula with a helpless population that has been exposed to the Turkish plunder and the oppression over the centuries. Living in a constant fear and under a constant pressure to sustain life, the submissive mentality of depressed and servile people developed. The syndrome of the characteristics of the Rhine character consists of traits: timidity, fatalism, malice, distrust, pragmatism, cunningness, egoism, blind loyalty to the master, humility towards the powerful and cruel attitude towards the powerless, as well as moral mimicry. This archetype largely explains the genesis and the reasons for the historical and political decisions made by the Serbian intellectual and political elite at the beginning and at the end of the 20th century.

However, the described archetype is not a sufficient cause for the creation of a social environment that results in corruption as a dominant feature of the rule of law. Namely, the enslaved people who lived in a constant fear and pressure, in addition to suffering, was characterized by stubbornness, the ideal of justice, the resistance and the struggle for liberation, and these aforementioned characteristics are not the primary characteristics of a corrupt person. Therefore, in addition to the psychology of personality and archetype, i.e., an innate pattern of thinking, feeling and acting, created as a result of centuries of experience of generations of ancestors, requires another social phenomenon, which will create a representative selection of corrupted individuals, who will then shape the social environment according to the dominant model.

\section{Liberation Wars and Reproductive Potential}

The World War I was fought from 1914 to 1918, between two military-political alliances. The immediate reason for the war was the assassination of the heir to the Austro-Hungarian throne, the Archduke Franz Ferdinand, in Sarajevo on June 28, 1914, when he was assassinated by Gavrilo Princip, a Serb from Bosnia, which was then the constituent part of the Austro-Hungarian monarchy. The declaration of war by the Austro-Hungarians to the Kingdom of Serbia was activated through several alliances that initiated chain reactions of the declaration of war. On one side there were the Central Powers, which consisted of: Germany, Austria-Hungary and Turkey, joined by Bulgaria in 1915. On the opposite side, there was the triple Entente, which consisted of France, the Great Britain and Russia, with their allies, who were joined by Italy after the Treaty of London in April 1915, while the United States entered the war on the side of the Entente in April 1917. The most obvious consequence of the World War I was a new territorial division of Europe, which was entered with over 15 million victims of war and more than 20 million wounded. During the First World War, the Kingdom of Serbia lost about 1,200,000 inhabitants, which made up almost a third of the total population or even about $60 \%$ of the male population.

The First World War mobilized over 60 million people in Europe, which was joined by the mass mobilization of the military able-bodied population in Serbia. Only women, children and invalids from the previous Balkan wars remained in the Serbian villages, which the Kingdom of Serbia fought against the Ottoman Empire in period from 1912 to 1913. After the First World War, in which $60 \%$ of the Serbian male population was slaughtered, in addition to survivors and the invalids from the Balkan wars, the largest reproductive potential was consisted of deserters, cowards, war profiteers, collaborators, etc. This very genetic potential 
represents a representative capacity, which, by multiplying over the next few generations (generation is a time interval of 20-25 years), can provide a critical mass that will shape the social environment according to the dominant model. In a social environment shaped in a such manner, the individuals do not have necessarily to know each other's personally, in order to interact through the social structures, i.e., systems of institutions, in order to obstruct the legal rules that entered into force. This effect is the result of achieving a critical mass of a familiar behavior, which I shall explain with the following example.

Namely, "The Hundredth Monkey Effect" is the name of an experiment that began in 1950 and examined the behavior of Macaque monkeys on the Japanese island of Koshima. Towards the end of his research in 1979, the South African zoologist Lyall Watson (1939-2008) published a book, titled as "A Life Tide", in which he systematized experimental experiences. The experiment was later challenged in one part. However, for the purpose of this analysis, the official version will be used. Namely, in 1952, a group of scientists started giving monkeys a special variety of sweet potato, which the monkeys liked. However, as they threw the potatoes on the ground, the potato was spiced with the tasteless grains of sand on the shore. Soon, the young monkey named Imo, discovered that the mentioned problem is to be solved by washing potatoes in the sea and showed it to her mother. Later, the other monkeys in the group began to apply the skill that Imo introduced them to, and more and more of them enjoyed clean potatoes. And then in 1958, a miracle happened, about which Lial Watson wrote in his book: "In the fall of that year, a certain number of monkeys on the island of Koshima washed the sweet potatoes in the sea. Suppose, e.g., that the number of monkeys was 99 and that on Tuesday at eleven o'clock a.m., another monkey joined the group that was washing the potatoes. And it was that very hundredth monkey that broke through some boundaries, i.e., the critical mass, so that evening almost all the monkeys did the same as he did. Not only that, that very habit skipped the natural barriers and spontaneously began to spread to colonies on the other islands where the monkeys were being in physical contact...."

So, if a sufficient number of members of one species learn (adopt) one matter, the effect will be the same as if everyone had learnt it, even if they do not necessarily need to be physically present in the studying process. We were driven to conclusion on the ground of the stated above, that when a critical mass of corrupt individuals was established, representing the "rule of law" in the system of position (status), the newly established, parallel institutions within the "rule of law" were formed, which functioned smoothly, according to their corrupt rules.

We can now conclude that in a certain interval of time, the social processes arising from spontaneous or imposed circumstances can form a critical mass of familiar behavior, which will shape or reshape the social environment according to the dominant model. In our example, the psychology of personality, combined with the archetype, i.e., the innate patterns of behavior inherited from the generation of ancestors, and the war-stimulated selection of reproductive potential, can create a critical mass of familiar behavior, which will be shaped by the dominant model, i.e., reshaped the previous social environment.

\section{Conclusion}

At the summit in London in 2018, the governments of the Western Balkan countries committed themselves to the fight against corruption within the "Berlin Process", and the initiative is 
aimed at strengthening regional cooperation between the countries of the Western Balkans. However, after three years, the GI-TOC report, which monitors the fulfillment of commitments made by the Berlin Process, states that the Western Balkans are making progress on anti-corruption strategies but there is still lack of implementation of these strategies.

Methodologically and strategically, the fight against corruption can approach in two ways: 1) Fight against the consequences of corruption and 2) Fight against the causes of corruption. The fight to prevent consequences of corruption focused on reforms of the legislation, judiciary system, police, state administration, etc. However, this "perpetum mobile struggle" only stops corruption for a moment. As the strategy for combating consequences of corruption has been developing in the same way and experiences have shown much faster, the adaptation of corruption to the implemented reforms has been developing, i.e., legislative changes that will be combating corruption more effectively. In fact, the fight of the consequences of corruption is initially lost fight against the corruption. It cannot be confirmed experimentally yet, but according to theoretical assumptions, it can be hypothetically claimed, that the only certain fight against the corruption, in fact is the fight against the causes of corruption. If we have stated the causes of corruption on the previously mentioned examples, i.e., psychology of personality, archetype and reproductive potential, then only the modification of the above factors can lead to satisfactory results. On the described genesis of corruption in Serbia, and as an example for any other country of the colonial past, it is necessary to implement intensive social changes that will initiate the creation of a new representative selection of archetypes. However, in today's time of popularizing freedoms and protecting various vulnerabilities, the stated fight against the causes of corruption represents a radical approach to the mentioned problem and is not possible.

However, even if there is a cognitive i.e., the willing moment of the Serbian people to suppress corruption within its social structure, it does not have the capacity to implement it on its own. Factors that once initiated the formation of an archetype can only initiate the formation of a new archetype. Thus, the once conquered countries, regardless of whether they have won freedom in the meantime or not, and the most of them are still situated in a colonial status according to the norms of the contemporary societies, can overcome the dominant corruption in their society only by creating a new archetype, which can be initiated only by former or any other new conqueror. When asked how long this process would expect to last, I often offered the following answer: " $A$ change in the policy of the certain country can be implemented in 6-7 months, a change in the economy in 6-7 years, while a change in the awareness of a certain nation lasts at least 6-7 decades, i.e., three generations." The largest number of the contemporary societies of the colonial past have neither the will nor the capacity to change the state of the current corrupt powerlessness - (anarchy).

\section{References}

Agatiello, O. R. (2010). Corruption not an end. Management Decision, 10(48), 1456-1468. https://doi.org/10.1108/00251741011090270

Aidt, T. S. (2009). Corruption, institutions, and economic development. Oxford Review of Economic Policy, 2(25), 271-291. https://doi.org/10.1093/oxrep/grp012 
Bardhan, P. (1997). Corruption and development: A review of issues. Journal of Economic Literature, 3(35), 1320-1346. www.jstor.org/stable/2729979

Barr, A., \& Serra, D. (2010). Corruption and culture: An experimental analysis. Journal of Public Economics, 2(94), 862-869. https://doi.org/10.1016/j.jpubeco.2010.07.006

Budak, J., \& Rajh, E. (2014). Corruption as an obstacle for doing business in the Western Balkans: a business sector perspective. International Small Business Journal, 2(32), 140-157. https://doi.org/10.1177/0266242613498882

Cvijic, J. (2020). Psychological characteristics of southern Slavs and Ethno psychology in Serbia. Belgrade: Serbian Academy of Sciences and Arts. Retrieved from http://www.knjizara.com/Psihicke-osobine-Juznih-Slovena-Jovan-Cvijic-115188

Dreher, A., Kotsogiannis, C., \& Mccorriston, S. (2007). Corruption around the world: Evidence from a structural model. Journal of Comparative Economics, 3(35), 443-466. https://doi.org/10.1016/j.jce.2007.07.001

Global initiative - Against transnational organized crime. (2021). Western Balkans anti-corruption pledges monitor. from https://globalinitiative.net/tool/anti-corruption-monitor/

Heidenheimer, A. J. (1996). The topography of corruption: Explorations in a comparative perspective. International Social Science Journal, 3(48), 337-347. https://doi.org/10.1111/1468-2451.00036

Howard, M. (2003). The First World War. Oxford University Press. Retrieved from http://www.gettextbooks.com/isbn/9780199205592/

Kuka, M. (2003). Utopia of Expectation. Belgrade: author's edition. Retrieved from http://www.gettextbooks.com/isbn/9788690316731/

Kuka, M., \& Krunic, M. (2020). The hypothesis of the predetermination of individual psycho-physical capacities. International Journal of Advanced Research, 3(8), 865-869. https://doi.org/10.21474/IJAR01/10850

Miller, W. L. (2006). Corruption and corruptibility. World Development, 2(34), 371-380. https://doi.org/10.1016/j.worlddev.2005.03.008

Peter H. (2013). The Great War: A Combat History of the First World War. Oxford University Press. Retrieved from http://www.gettextbooks.com/isbn/9780199976270/

Sah, R. (2007). Corruption across countries and regions: Some consequences of local osmosis. Journal of Economic Dynamics and Control, 8(31), 2573-2598. https://doi.org/10.1016/j.jedc.2006.09.002

Tönnies, F. (2018). Gemeinschaft und Gesellschaft, Leipzig: Fues's Verlag. Wissenschaftliche Buchgesellschaft. Darmstadt. Retrieved from http://www.gettextbooks.com/isbn/9780243557509/ 


\section{Macrothink}

International Journal of Social Science Research

ISSN 2327-5510 2021, Vol. 9, No. 2

Torsello, D., \& Venard, B. (2015). The anthropology of corruption. Journal of Management Inquiry, 1(25), 34-54. https://doi.org/10.1177/1056492615579081

Watson, L. (1980). Life Tide. London: Hodder \& Stoughton. Retrieved from http://www.gettextbooks.com/isbn/9780553134704/

Wundt, W. (2017). Elements of Folk Psychology. Outlines of a Psychological History of the Development of Mankind, New York: George Allen \& Unwin Ltd. Retrieved from http://www.gettextbooks.com/isbn/9781330360279/

\section{Copyrights}

Copyright for this article is retained by the author(s), with first publication rights granted to the journal.

This is an open-access article distributed under the terms and conditions of the Creative Commons Attribution license (http://creativecommons.org/licenses/by/4.0/). 